\author{
Elena G. Vyushkina
}

Saratov State Law Academy, Russia

\title{
INTERNATIONAL COMPETITIONS FOR LAW STUDENTS: THE DEVELOPMENT OF COMMUNICATIVE AND PROFESSIONAL COMPETENCES
}

\begin{abstract}
The paper deals with a practical approach to developing of law students' communicative and professional competences within a one-term, optional, cross-curricular course. The author, whose principal occupation is teaching Legal English, was offered the opportunity to train a team of law students to take part in the national rounds of the International Client Consultation Competition. Since then, the author has been involved in coaching teams for law students' competitions and the author's three year work has resulted in framing an experimental cross-curricular course "Client Consultation in English". The background and necessity for the development of the course are outlined in the paper, along with a brief overview of teaching legal skills in Russia and general information about international competitions for law students. The basic elements of the course are described, as well as the methods used by the author for training students' teams. A similar framework is being used now for creating another cross-curricular course "Legal Negotiations in English".
\end{abstract}

Keywords: legal English, communicative competence, professional communication, interviewing skills, client consultation

The Longman dictionary of contemporary English defines a lawyer as "someone whose job is to advise people about laws, write formal agreements, or represent people in court" (2001:796) and it also gives references to such entries as advocate, attorney, barrister, and solicitor. The latter terms are used to name representatives of the legal profession in diverse legal systems underlining differences in their duties and obligations. To avoid ambiguities, the following definition of the word lawyer will be used in this paper: a "person who has studied law and can act for people on legal business" (Collin, 1992:136).

Over the past twenty years, the legal profession has become extremely prestigious and very popular in Russia and one of the reasons for this is the continuing growth of the legal services market (Muranov, 2009; Mura- 


\section{Elena G. Vyushkina}

nov, Chernyakov \& Partners, 2012). But this growth does not guarantee employment to law school graduates, because their number increases every year, too. According to data presented by Academica.ru (2013) about five hundred institutions of higher education offer legal education and Enrollee2013 Navigator (2013) gives an estimate of 20,000 places available for future law-students.

To become competitive, future lawyers should clearly realise what their professional duties and obligations will be and what knowledge and skills they will need. Zhalinskii (1997) states that a lawyer's professional activity is carried out through interaction with other people, i.e. through the process of interpersonal communication. So communication skills are crucial for lawyers, whether it be when they are talking to a client, giving a speech in court or negotiating. Thus future lawyers should get to know how to present their point of view in an impressive and effective way. Moreover, if they want to be successful in the international field they should be able to do so, not only using their native language, but in English as well.

How can communicative competence be acquired by law students? What subjects develop such professional skills as interviewing, questioning, analysing, and negotiating? Is it possible to develop and master all these skills within one course? If yes, what kind of course should it be?

\section{Some Facts about Teaching Legal Skills in Russia}

Legal education in Russia differs greatly from the Anglo-American pattern. Firstly, there are two types of Law Schools in Russia: the first is a Law School / Department / Faculty within a university; the second is a specialised institution of higher legal education usually called either "Law Institute" or "Law Academy". Both types of institutions used to award a specialist degree after 5 years of undergraduate studies, and today they award both a specialist degree (5 years) and a Bachelor's degree (4 years). Thus legal education is available at the undergraduate level. It exists at a postgraduate level as well, and Law School graduates can pursue a 'kandidat nauk' degree (a Russian intermediate degree between a Specialist and a Doctor) or a Master's degree. The highest academic degree in legal education is the Doctor of Law.

Secondly, Law Schools' curricula used to be uniform all over the country until recently and, still, there is a federal compulsory core for the legal education curriculum with a smaller regional/institutional part (Or- 
der, 2010). In general, Law Schools' curricula are knowledge-oriented, and little time is assigned to developing practical skills (actions at the scene of a crime, e.g., a one-term course Criminal Investigation Technique) or public speaking skills (e.g., a one-term course on the Russian Language and Speech Culture). The basic skills of lawyer-client intercourse are mastered by students when they study the Lawyer's Code of Ethics within a one-term course devoted to the legal profession / bar / advocacy (because of great differences in legal systems, sometimes it is easier to describe a concept than to find a one-word equivalent); and there are no courses teaching legal negotiations as a separate discipline in most Law Schools in Russia.

As for foreign languages, and English in particular, it should be noted that although the subject is compulsory, the number of academic hours for the course has been reduced from about 300 to 100 in recent years. One of the reasons is a general reduction in academic hours after the transition to the Western tradition of education and the elimination of the specialist degree in training lawyers. Five years ago, students had English classes twice a week for 5 terms; today, they learn English only during their first year of study. There is no doubt that students' independent work should be intensified significantly, but it is very difficult to persuade first-year law students to pay more attention to a foreign language, because they have just entered a new stage of their lives, and studying subjects directly connected with their major, jurisprudence, seems much more important to them.

For those who want to improve their knowledge of English, there is an opportunity to take extra English classes for fees within the framework of extracurricular activities. In Russia many institutions of higher education provide an additional qualification programme "Translator in the sphere of professional communication" (Order, 1997). Students who choose this kind programme have from 6 to 10 academic hours of additional training every week.

The programme includes theoretical courses such as Lexicology, Grammar, Stylistics, Theory of Translation, etc., in addition to practical classes in everyday and legal English (Syllabus, 2011). The students involved in the programme are usually highly motivated, although, sometimes they need additional incentives. One of the ways of supporting students' motivation to continue acquiring and developing English language communication skills is to "put the language they are learning into practice instantaneously" (European language policy and CLIL, p. 2). This is possible by engaging them in participation in international competitions for law students. 


\section{International Competitions for Law Students}

Dr. Larry Teply, Professor of Law at Creighton University Law School and the chair of the International Negotiation Competition executive committee, in his book Law School Competitions in a Nutshell (2003) names three types of competitions: moot courts, negotiation, and client counseling. All these competitions are used in Law Schools as extracurricular activities and are launched to increase students' interest in practical vocational skills. Participation in any competition, at any level, is greatly beneficial for law students. In these simulations they get a grasp of real professional experience and can learn much from practicing lawyers who are involved in the competitions as arbiters of the events.

Moot courts are the most traditional type of competitions for law students. Not surprisingly, Wikipedia gives a list of more than 20 notable competitions covering different branches of law with Jessup and public international law in first place. (Table 1).

Table 1

The most popular competitions for law students

(an extract from the List of notable competitions http://en.wikipedia.org/wiki/Moot_court)

\begin{tabular}{|l|l|l|c|}
\hline \multicolumn{1}{|c|}{ Competition } & \multicolumn{1}{|c|}{ Subject matter } & \multicolumn{1}{c|}{$\begin{array}{c}\text { Annual } \\
\text { participation }\end{array}$} & $\begin{array}{c}\text { National or } \\
\text { regional } \\
\text { rounds }\end{array}$ \\
\hline Jessup & Public international law & $600-650$ teams & Yes \\
\hline Willem C. Vis Moot & $\begin{array}{l}\text { International commercial } \\
\text { arbitration }\end{array}$ & $280-300$ teams & No \\
\hline Price Media Law Moot & International media law & 115 teams & Yes \\
\hline $\begin{array}{l}\text { International Maritime Law } \\
\text { Arbitration Moot }\end{array}$ & $\begin{array}{l}\text { International maritime } \\
\text { law }\end{array}$ & $15-20$ teams & No \\
\hline $\begin{array}{l}\text { Sir Manfred Lachs Space Law } \\
\text { Moot }\end{array}$ & Space law & $60-70$ teams & Yes \\
\hline $\begin{array}{l}\text { ELSA World Trade Organisation } \\
\text { European Law Students' Association) }\end{array}$ & World Trade Organisation & $50-70$ teams & Yes \\
\hline $\begin{array}{l}\text { European Law Moot Court } \\
\text { Competition }\end{array}$ & European law & $80-100$ teams & Yes \\
\hline $\begin{array}{l}\text { International Environmental } \\
\text { Moot Court Competition }\end{array}$ & $\begin{array}{l}\text { International } \\
\text { environmental law }\end{array}$ & 20 teams & Yes \\
\hline $\begin{array}{l}\text { Frederick Douglass Moot } \\
\text { Court Competition }\end{array}$ & $\begin{array}{l}\text { Domestic/International } \\
\text { law }\end{array}$ & $100-125$ teams & Yes \\
\hline ICC Trial Competition & International criminal law & $12-19$ teams & Yes \\
\hline
\end{tabular}


Jessup, which dates back to 1960, is one of the most prestigious moot court competitions (Philip C. Jessup, 2013). It is a simulation of a dispute between imaginary countries before the International Court of Justice. Jessup national rounds have been organised in more than 90 countries in recent years. International public law is also dealt with at the Telders International Law Moot Court Competition that originated in 1977 and is held at the Peace Palace in The Hague (Telders International Law Moot Court Competition 2014, 2013). Besides international public law, students participating in other competitions deal with international commercial arbitration, international humanitarian law, space law, international criminal law, international human rights law, etc. To take part in these competitions, teams must either be the winners of national rounds, or pay the registration fee which is high, or both.

Law schools use moot courts as an extracurricular activity, aimed at developing research, writing and oral argument skills. It is important to stress that a moot court is different from a mock trial, which is also used to elaborate public speaking experience. The former relates to an appellate court or arbitration, while the latter simulates a jury trial. In moot courts the focus is on applying the law to established facts which are given to teams of law students. The students act as defenders, prosecutors, and counsels. They write memorials and speak in front of a panel of judges. Therefore, in order to succeed, the participants must show highly developed communication skills. Moreover, more than half of the participants should have a good command of foreign language (English) communication skills.

In Russia, Jessup national rounds have been held since 2002 (The Philip C. Jessup International Law Moot Court Competition, 2013) and our institution sends a team there every year. The best result achieved was second place and this was mostly due to the great work of the team coach for the year in question. In fact, coaching a team for a moot court competition is work for a law teacher, because a particular branch of law is dealt with, and legal knowledge and understanding are crucial for success. A language teacher can only assist in training a team for a moot court competition.

But there are some other communication oriented competitions where a language teacher can play a key role, applying to law teachers for support when necessary. The International Chamber of Commerce mediation competition brings together more than sixty teams from all over the globe (What is the Mediation Week, 2013). It is held in Paris annually. There are no national rounds, but the registration fee is somewhat high. Moreover, this is not a "pure" law students' competition, because business students are involved in it as well. 
The International Negotiation Competition (INC) dates back to 1998, when four teams from the USA, Canada, England, and Australia met in Pepperdine University, Malibu, CA (International Negotiation Competition, 2013). The competition is modeled on the American Bar Association Negotiation competition. It is a simulation of legal negotiations aimed at resolving a dispute or contracting an international transaction. The INC is held annually in July in different countries. Winners of the INC national rounds are admitted to participation and no entrance fee is charged. In 2013, twenty teams from all over the world visited Chapman University, Orange, CA, to take part in this competition. There were nine teams from English speaking countries; continental Europe was represented by three teams; five teams came from Asia; and Africa and Latin America each sent one team. A team from our institution also participated in the INC 2013, representing Russia: this coincides with the fact that our institution has been selected to organise national rounds in the 2013-14 academic year. According to the INC rules an institution can send a team if it offers prospects of organising national rounds in the following academic year. It is noteworthy that more than half of the teams were not native speakers of English, and it was a non-native speaking team - the team from Germany - who won the first prize.

The International Client Consultation Competition (ICCC) is sponsored by the Law Student Division of the American Bar Association and, like the INC, is held annually in different countries, in April (About ICCC, 2011). It is also necessary to have won national rounds to participate in the ICCC and about 20 teams come to the contest every year. Geographical representation is very wide. The students of our institution have participated in the ICCC national rounds since 2010 .

The author has trained students for both the ICCC and the INC and has worked out a practical approach to developing the communicative and professional skills necessary for the participants to succeed. The development of this new course represents the first experience of using a somewhat new and very popular methodology in Europe - Content and language integrated learning (CLIL).

\section{Cross-Curricular Course "Client Consultation in English"}

\section{Background}

The International Client Consultation Competition is a simulation of an initial lawyer-client interview so the participants must demonstrate a high 
level of professional communication along with the skills of analysis and knowledge of law. An actor performs the client's role and law students play the roles of lawyers. In Russia one of several possibilities for developing professional skills such as interviewing a client or analysing case facts is available in law clinics but, for instance, in our institution not many law students are involved in this process, due to the fact that such internships are not compulsory. Moreover, the ways and manner of client counseling, which the students acquire while working in a law clinic, differ from those used in an international firm. For instance, legal aid provided in a law clinic is intended for low-income clients and that is why it is free. Thus, fee issues are not discussed with clients, even though they are required to provide evidence of their financial status.

The competition format is similar at national and international levels: preliminary rounds, semifinals, and finals. The only difference is that at the national level (in Russia) there are two teams competing in the semifinals and final, while at the international level three teams strive for victory. About two to three weeks before the competition, each team receives three short secretary's memos indicating the problems that the participants will have to deal with in each round. But these memos are less than hints. For example, in 2011 when the topic was Professional Responsibility and Ethics in the Law Office, one of the memos read: "John/Joanne Jones has made an appointment. He/she wants to discuss a dispute between his/her company, Envirosupport, and a company who purchased some antifreeze from Envirosupport."

The branch of law to be used during the consultation is announced in advance (usually after the international competition for a current academic year has ended). It is a somewhat broad indication: family law, white-collar crimes, lawyers' ethics, employment law, etc. According to the ICCC rules, the law students acting as lawyers use national law within the competition at both the national and international levels.

The ICCC was introduced to Russia in 2007, when the Russian team from Kazan Federal University took part in the International Client Consultation competition held in Sydney (History of Competition in Russia, 2013). In 2008, national rounds were organized for the first time in Kazan. Starting with eight teams in 2008 the ICCC-Russia has grown to twenty teams in 2012, and Russia has won second place at the international level in both 2008 and 2009.

Interest in the competition among law students is very high, because they realise the importance of the professional skills acquired while preparing for the competition and the significance of indicating in their CVs, the 


\section{Elena G. Vyushkina}

fact that they have been participants, or semifinalists, or winners, for a future professional placement. It is no wonder that two students initiated the participation of our institution in the national rounds of the competition in 2010. They found the Call for Participants on the Internet and asked the author to become their coach, as the competition registration form had a requirement of this kind; they had been members of the author's Legal English class in the previous academic year.

The general description of the upcoming event given in the Call for Participants did not provide much information about the competition or its format, nor was there enough coverage of the ICCC on the Internet at that moment. Thus, most of the preparation consisted of training topical vocabulary - that year it was white-collar crimes - and brainstorming the case facts from the received memos.

In terms of results, this first experience was not successful, but it was very effective and useful for understanding the essence of the competition. Usually there is a workshop held on the first day of the event. That year it was a lecture by Selene Mize, a coach from New Zealand, whose teams participated in the international finals, winning the second and third places several times and finally the ICCC in 2012. Unfortunately, a visa issue prevented her from coming to Kazan in person, but she used Skype to tell the participants about the basic principles of an initial lawyer-client interview. Moreover, a meeting for coaches was organized. It is interesting to note that half of the coaches were law teachers, mostly law clinic directors, and the other half were teachers of English. The National ICCC representative provided a generous amount of materials: a DVD with the Kazan team's presentation at the 2008 international competition, video records of other teams' presentations, notes and suggestions of the previous year's participants. So it was a busy night when our team reorganised its drafts. The team was not among semifinalists but a plan of preparation for the competition in the coming academic year was reached.

\section{Course Outline}

It is obvious that a good command of English is not enough to succeed in the competition and that professional communication skills are also very important. As mentioned before, Russian law schools curricula contain mostly theoretical courses. Therefore, when starting to train law students for professional contests, teachers should cover general aspects of lawyer-client communication and issues of intercultural contacts along with appropriate English language skills. 
Strictly speaking, the course of preparation for the ICCC started as an extracurricular activity for volunteer students. But after getting some experience of training students for the competition and participating in the national rounds, the set of activities turned into a planned syllabus with the following objectives put forward:

- to introduce the goal and structure of the competition;

- to explain the main idea of the initial lawyer-client interview;

- to teach specific language patterns of the interview, opening and closing structures;

- to develop listening skills;

- to master skills of eliciting information; and

- to elaborate critical thinking.

According to the objectives, the course is divided into four unequal parts: an introduction, specific language training, interview practice and brainstorming of national rounds memos.

Introduction. At the first meeting of a group which usually consists of 8-10 students, the students are told about the competition, a syllabus is introduced, and a list of links and literature is given (see Appendix). As a rule, the previous year's team members come and share their experiences. They remain involved in the preparation process helping with the composition of scenarios and acting as clients.

There are several videos devoted to client counseling which can be found on the Internet (see Appendix). Their duration is from five to ten minutes and they are worth watching in class with further discussion. As a home assignment, the students are asked to watch some records of the ICCC final rounds: the ICCC 2007 video is on the competition website, consultations of the U.S., England and Wales, New Zealand teams - the ICCC 2010 finalists - are uploaded on YouTube, and the Cambodian Team presentation at the ICCC 2012 can also be found on YouTube. Another home assignment is to review the federal law "On Advocacy and the Bar in the Russian Federation", the Lawyer's Professional Code of Ethics and to prepare a summary (in English) of basic principles of an initial lawyer-client interview in Russia.

Specific language training. At the beginning of this stage the first five to seven minute long opening episodes of interviews are watched by the whole group in class. The students are encouraged to compare these fragments and to list the points to be covered at the beginning of an interview. These compulsory points are ice-breaking/small talk, timing, confidentiality, presence of two lawyers, conflict of interests, fees. Most of the students are in their third or fourth year of study and some of them have an internship in a law clinic. Having reviewed the documents mentioned above as their 


\section{Elena G. Vyushkina}

home assignment and relying on their experience, the students compare the pattern for opening the interview followed at the competition with the one used in real life in Russia, which enables them to highlight and comment on any differences. An activity of this kind promotes critical thinking and speaking skills.

Several language patterns characteristic of the opening stages of the interview are given to the class: students' handouts are composed of Internet video scripts recorded by the author. The students have different variants of wording for the issues to be covered in the opening stages of the interview and can choose what they like most and add something themselves. A couple of lessons are devoted to practicing this part of the interview. The students work in groups of three, changing roles as lawyers and as clients.

Not only the handouts prepared by the teacher can be used at this stage. Nowadays the list of Legal English textbooks available in Russia has become rather long and these books offer not only reading and topical vocabulary tasks, but deal with developing listening and language use skills as well. In the Cambridge Introduction to International Legal English (Krois-Linder, Firth \& TransLegal, 2008) there are exercises devoted to: a) conducting an initial lawyer-client interview; b) asking for clarification and giving explanations; c) giving advice; d) explaining law terms to non-lawyers. These exercises are scattered through different units, but it is not a problem to extract them and use them when necessary. At the same time, topical vocabulary can be reviewed.

Listening skills and skills for eliciting information are trained together. At first such communication techniques as active listening are introduced to the students. They are offered practice in re-stating and paraphrasing. These exercises are also useful for clarifying the information gained during an interview. Parallel to paraphrasing language patterns for showing interest and empathy are trained. Then types of questions are reviewed and the students are asked to explain the difference in the purposes of asking open/closed questions during the interview. Usually they do not have any problems with indicating in their answers that open questions are used to get information and closed questions are aimed at checking understanding of what has been said.

Students are given the task to prepare stories connected with the branch of law to be used at the competition. Working in pairs or groups of three, the students use these stories in class. While considering their stories, they are asked to put the facts into three groups: general facts are told to the students acting as lawyers at the beginning of an interview when a student acting as the client presents his or her case, some specific information is 
disclosed if the client is asked direct questions, and the third part is shared with the lawyers only if the client feels that the lawyers are trustworthy. In fact the third stage of preparation begins here.

Interview practice. At the beginning of the practice stage interviews are not complicated by psychological elements, but it is necessary to teach students to deal with difficult clients at this stage as well. Although most characters presented at the attended competitions were average 'normal' people, students should know what to do if a client does not proceed in an expected way. The students are asked to brainstorm and enumerate the types of difficult clients they can imagine. Students easily state that clients can be emotionally distraught, reluctant, talkative or angry. Those who work in a law clinic also mention aged or infirm clients. Usually it is the teacher who tells the students that a client can be lying. It is interesting to note that sometimes the students may even ask why a client would lie. Thus after general patterns have been trained, the students are given the task of attempting to make their clients' characters more complex. The students are good actors and are very imaginative. They create very interesting and funny situations: once a client was an elderly book-keeper fired from a bank, another time a jealous officer broke into the lawyers' office, etc.

Another language and critical thinking skill to be trained is summarising. It is very important to get a clear picture of a client's case. That is why the lawyers should elicit pure facts from a client's story and check that their understanding is correct. They should use simple and clear language while giving this summary to the client. Exercises from Introduction to International Legal English (Krois-Linder et al., 2008) and International Legal English (Krois-Linder \& TransLegal, 2006) directed at paraphrasing legal English into plain language are very helpful.

From a language teacher's point of view the most difficult aspect of coaching a team for a law student competition is scenario drafting/composition. There are several ways of overcoming this difficulty. The first thing to do is to apply to colleagues from law departments for advice. They are usually ready to help and suggest a couple of books. To translate problems into English is not a problem for a language teacher. The disadvantage of this approach is that the problems are usually very short and devoted to one article or section of the branch of law studied, while the scenarios offered at the competition are sophisticated and can involve several legal issues.

Another way out of this difficulty was prompted by the Ulyanovsk University team coach during last year's national rounds. She is the head of a university law clinic and it is not a problem for her to compose a case. 


\section{Elena G. Vyushkina}

But what she usually does in the course of preparation for the national rounds is to tell students to write a scenario as a part of their home assignment. It should be mentioned that the students solve legal problems at seminars while studying various branches of law and have an idea as to what is supposed to be in a scenario. This method promotes critical thinking and enhances students' legal knowledge. The last but not the least source of ideas is common sense and the life experience of the coach. Moreover, the collection of cases has been growing constantly and even if they are not consistent with the topic of a given year, they are very helpful in interview practice and for the purposes of training critical thinking.

Brainstorming of the national rounds memos. At the final stage of preparation when 'secretary memos' are received, the brainstorming of possible cases begins. Both the English and Russian languages are used while trying to identify what has happened to a potential client. Ideally the discussion should be carried out only in English. All ideas, even unrealistic ones, are taken into consideration. It is worth mentioning that in 2012 our team managed to predict almost all the scenarios offered later at the national rounds. Key points were highlighted in a somewhat different way, but in general the students were well prepared. Using previously thought-out sets of facts, the coach plays the role of the client and the students practice the competition format.

Selecting an institution team for the national rounds. In the academic years 2010-2011 and 2011-2012 the teams were composed informally. The training group in the 2010-11 academic year was small; in 2011-12 it was not numerous either. So there were only two pairs of students to choose from. They were asked to perform the opening stages of an interview and teachers not involved in coaching acted as the jury. As a rule, the team selection process takes place in December as the national rounds application deadline is usually at the end of December. Both in 2011 and 2012 our institution team reached the semifinals and received very positive feedback from the judges.

In the 2012-13 academic year, the group of students involved in the preparatory work was more numerous and it was decided to carry out qualifying rounds at our institution. A date for the intra-institution competition was announced formally on our website. A panel of judges was specially chosen and consisted of both law and language teachers. An international student from Saratov Medical University who spoke English as a second, not foreign, language was invited to act as a client. Three teams were registered and took part in the competition. The students who came to watch the competition were really interested in this form of extracurricular activity 
and expressed a wish to join in with it in the next academic year. The winning team was very good. But unfortunately, there were no national rounds in 2013. Kazan Federal University held national rounds for 5 years, and the announcement of the $6^{\text {th }}$ competition was made, but in a couple of days it was recalled. The national representative told us that at the last moment the university authorities refused to support the organising committee and it was too late to move the rounds to another institution.

\section{Conclusion}

The teaching of highly qualified specialists in law is a complicated educational process where acquiring legal knowledge and mastering professional skills should be balanced. If the curriculum does not include specialised courses aimed at developing specific skills providing high levels of professional communication, then extracurricular activities such as preparation for, and participation in, international competitions for law students can be recommended.

Different competitions require diverse types of communicative professional competence such as oral argument, negotiating, or client counseling. Although there is much in common in the methods for developing and improving these skills, it is better to focus on one sphere of professional performance.

On the matter of client counseling in English, it is necessary to note that developing this form of communicative professional competence can be carried out either within a Legal English course or in a separate one-term course structured in the following way:

- Introduction to the topic: general information on the lawyer-client initial interview in the Anglo-American culture and in Russia; an overview of the ICCC format;

- Language training: language patterns at the beginning of an interview and in the final stages; language for acquiring information, asking for clarification, giving explanations, summarising;

- Counseling practice: preparing case scenarios; conducting interviews, analysis of the interviews;

- Straightforward preparation for the competition: brainstorming memos sent by the organising committee of the competition.

Developing a cross-curricular course is difficult and challenging work. But a 'can do' attitude, colleagues' support, and students' great desire to succeed in studying, in the competition, and, finally, in their careers help 
a teacher to meet the challenge. Training students to participate in professional contests at different levels is a complex and time-consuming, but rewarding task.

\section{R E F E R E N C E S}

About ICCC. (2011). Retrieved October 19, 2013, from: http://www.maastricht university.nl/web/Faculties/FL/Theme/Education/MootCourts/Client ConsultationCompetition/ICCC/AboutICCC.htm

Academica.ru. Search Results. Retrieved October 19, 2013, from: http://academica. $\mathrm{ru}$ /vysshee-obrazovanie/030000-Gumanitarnye-nauki-JurisprudencijaGosudarstvennyj-vuz/stranitsa_1/

Collin, P.H. (1992). Dictionary of Law (2 $2^{\text {nd }}$ ed.). Teddington: Peter Collin Publishing Ltd.

Enrollee-2013 Navigator. Retrieved October 19, 2013, from: http://ria.ru/sn_edu/ 20130315/923532085.html.

European language policy and CLIL: A selection of EU-funded projects. Retrieved September 24, 2013, from: http://www.ua.gov.tr/docs/avrupa-dil\% $3 \% \mathrm{~B} 6 \mathrm{~d} \% \mathrm{C} 3 \% \mathrm{BCl} \% \mathrm{C} 3 \% \mathrm{BC} /$ finarep_en.pdf?sfvrsn=2.

History of Competition in Russia. (2013) История конкурса в России. Retrieved October 19, 2013, from: http://kpfu.ru/main_page?p_sub=15655.

International Negotiation Competition. Retrieved September 24, 2013, from: http: //www.chapman.edu/law/competitions/dispute-resolution/internationalnegotiation-competition/.

Krois-Linder, A., Firth, M. \& TransLegal. (2008). Introduction to International Legal English. Cambridge, UK: Cambridge University Press.

Krois-Linder, A., \& TransLegal. (2006). International Legal English. Cambridge, UK: Cambridge University Press.

Longman Dictionary of Contemporary English. Third edition with New Words supplement (2001). Pearson Education Limited.

Muranov A. (2009). Внутренний российский рынок платных юридических услуг: некоторые иифры [Russian Market of Legal Services: Some Figures] Retrieved October 19, 2013, from: http://referent.mubint.ru/8/7175?try.

Muranov, Chernyakov \& Partners. (2012). Глобальный рынок юридических услуг: некоторье тенденции и иифрь [Global Market of Legal Services: trends and figures]. Retrieved October 19, 2013, from: http://www.lawfirmmanage ment.ru/publications/articles/194-muranov-lawmarket-research-2012.html.

Philip C. Jessup International Law Moot Court Competition. (2013). Retrieved October 19, 2013, from: http://www.ilsa.org/jessuphome. 
Order of 04.07.97 N 1435. (1997). Приказ от 04.07.97 N 1435 « присвоении дополнительной квалификации "Переводчик в сфере профессиональной коммуникации" выпускникам вузов по специальностям высшего профессионального образования». Retrieved October 19, 2013, from: http://www. edu.ru/db/mo/Data/d_97/1435.html.

Order of the RF Ministry of Education and Science. (2010). Приказ Минобрнауки РФ от 04.05.2010 N 464 «Об утверждении и введении в действие федерального государственного образовательного стандарта высшего профессионального образования по направлению подготовки 030900 Юриспруденция (квалификация (степень) “бакалавр")» Retrieved October 19, 2013, from: http://base.garant.ru/198430/.

Syllabus of the Programme "translator in the Sphere of Professional Communication". (2011). Учебно-методические комплексы, дополнительной к высшему образованию, программы "Переводчик английского языка в сфере профессиональной коммуникации". Retrieved October 19, 2013, from: http://test.ssla.ru/showl.phtml?departments/024-dop_obr.

Telders International Law Moot Court Competition 2014. (2013). Retrieved October 19, 2013, from: http://www.grotiuscentre.org/TeldersMootCourt.aspx.

Teply, Larry L. (2003). Law School Competitions in a Nutshell. (Nutshell series). West group.

The Philip C. Jessup International Law Moot Court Competition. (2013). Retrieved October 19, 2013, from http://www.whitecase.com/moscow-jessup/\#.UmSs 11OZZ4A.

What is the Mediation Week? (2013). Retrieved October 19, 2013, from: http:// www.iccwbo.org/training-and-events/competitions-and-awards/mediationweek/.

Zhalinskii, A. (1997). Профессиональная деятельность юриста. Введение в спеииальность [Lawyer's Professional Activity. Introduction to Profession]. Moscow: Publishing House BEK.

\section{Appendix}

\section{Websites and YouTube Video Links}

UTS Law Students' Society: Client Interview Tutorial http://www.youtube. com/watch?v=LoD1xOVFMgQ\&feature=related

ICCC 2011 http://www.maastrichtuniversity.nl/web/Faculties/FL/Theme/ Education/MootCourts/ClientConsultationCompetition/ICCC.htm

ICCC 2007 Video (Sidney, Australia) http://www.usyd.edu.au/lec/ICCC20 07/video.shtml OR http://sydney.edu.au/lec/ICCC2007/video.shtml

Louis M Brown Client Counselling Competition 2010 - United States team (Part 1) http://www.youtube.com/watch?v=5l-RxAO0nDE 


\section{Elena G. Vyushkina}

International Client Counseling Competition 2012 in Dublin, Ireland - Cambodian Team http://www.youtube.com/watch?v=mkbLS4Sfkl8

Client Interviewing Competition 2011 http://www.youtube.com/watch?v= F2FXvyR2MgA

ICCC home page http://www.brownmosten.com/ 